\title{
Выделение профессионально важных качеств инспектора Государственной инспекции по маломерным судам МЧС России
}

\section{Юлия С. Шойгу, Анастасия А. Тарасова*}

Федеральное казенное учреждение «Центр экстренной психологической помощи МЧС России», г. Москва, Российская Федерация

${ }^{*}$ E-mail: tvsova80@mail.ru

\begin{abstract}
Аннотация
Ввеление. Несмотря на Аостаточный накопленный опыт в области исследования разнообразных виАов профрессиональной Аеятельности, в настоящее время отсутствуют Аанные по психологическому изучению профессиональной Аеятельности инспекторов Государственной инспекции по ма^омерным судам МЧС России (Аалее - ГИМС МЧС России). В связи с этим возникла актуальная практическая необходимость в изучении специфики профеессиональной Аеятельности Аанных специалистов и в определении необхолимых профессионально важных качеств (Аалее - ПвК), влияющих на эфффективность выполнения этой самой Аеятельности.
\end{abstract}

Метолы. В исслеАовании приняли участие 275 инспекторов ГИМС МЧС России, проживающих в различных субъектах Российской Федерации. На основании экспертного опроса был подобран психодиагностический инструментарий, направленный на изучение интелмектуальной, когнитивной и мичностной сорер у обследуемых инспекторов ГИМС МЧС России. Общее количество экспертов состави^о 40 человек. А^я обработки полученных Аанных использовались методы математико-статистической обработки.

Результаты. С помощью проведения сравнительной процедуры успешных и неУспешных инспекторов ГИМС МЧС России вылелены ПВК, явАяющиеся среАством прогнозирования успешности профрессиональной Аеятельности инспекторов ГИМС МЧС России. Полученные ПВК разделены на 3 блока: интелмектуально-мнестический, эмоционально-личностный и мотивационно-волевой. Уровень выраженности кажАого ПВК опреАелялся по среднему значению в группе успешных специалистов. ОбсужАение результатов. Проведенное психологическое изучение продрессиональной Аеятельности инспекторов ГИМС МЧС России позволи^о опреАелить необходимые ПВК, Аетерминирующие успешность выполнения профрессиональных залач. Полученные Аанные позволят усовершенствовать мероприятия по проведению профессионального психологического отбора, а также определить степень соответствия психологических качеств канАидата требованиям специальности. 


\section{КАючевые слова}

профрессионально важные качества, профеессиональная деятельность, инспектор, психодиагностическое исследование, психодиагностический инструментарий, инАивиАуально-психологические характеристики, психофризиологические характеристики, успешность профессиональной Аеятельности, экспертный опрос, Аостоверность различий

\section{Основные положения}

- изучена специфрика профрессиональной Аеятельности инспекторов ГИМС МЧС России, а также опрелелена роль ПВК в их Аеятельности;

- на основе экспертного опроса определены индивидуально-психологические и психофризиологические ПВК, необходимые Аля эфрфективного выполнения профессиональной Аеятельности инспекторами ГИМС МЧС России;

- на основании экспертного опроса и математических методов выявлены по^ярные группы и статистически определена Аостоверность различий межАу успешными и неуспешными инспекторами ГИМС МЧС России, что является АОстаточным Аля прогнозирования успешности профессиональной Аеятельности инспекторов ГИМС МЧС России.

\section{Для цитирования}

Шойгу Ю. С., Тарасова А. А. Выделение профессионально важных качеств инспектора Государственной инспекции по маломерным судам МЧС России // Российский психологический журнал. - 2017. - Т. 14, № 4. - С. 267-295.

Материалы статьи получены 01.12.2017

UDC 159.9.072.592

DOI: $10.21702 /$ rpj.2017.4.13

\section{Professionally Important Qualities of Inspectors in the State Small Vessels Inspectorate of EMERCOM of Russia}

\section{Julia S. Shoigu, Anastasia A. Tarasova}

Center for Emergency Psychological Aid, EMERCOM of Russia, Moscow, Russian Federation * Correspondence author. E-mail: tvsova80@mail.ru

\section{Abstract}

Introduction. Recently, considerable attention has been paid to studying various kinds of professional activities. However, psychological studies on professional activities of inspectors in the State Small Vessels Inspectorate (SSVI) of EMERCOM of Russia are still lacking. The present study examines professionally important qualities which determine 


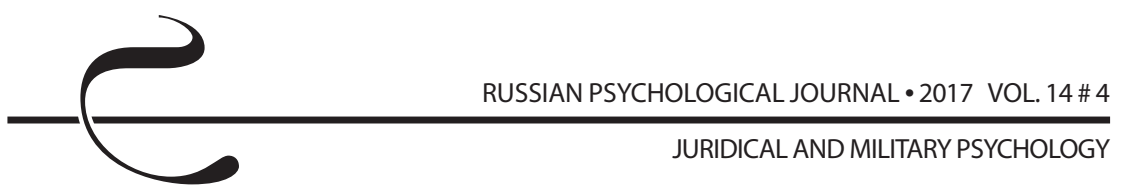

the efficiency of professional activities in this group of specialists.

Methods. The study involved 275 inspectors in the SSVI of EMERCOM of Russia residing in various federal subjects of Russia. An expert survey helped to choose psychodiagnostic techniques for studying intellectual, cognitive, and personal characteristics of inspectors in the SSVI of EMERCOM of Russia. The experts comprised 40 persons. The study employed methods for mathematical and statistical treatment of data.

Results. The comparison of sUccessful and unsuccessful inspectors in the SSVI of EMERCOM of Russia revealed the professionally important qualities that could predict the efficiency of professional activities in this group of specialists. The professionally important qualities were grouped as follows: (a) intellectual and mnestic, (b) emotional and personal, (c) and motivational and volitional. The level of each professionally important quality was measured by mean scores in the group of successful inspectors. Discussion. The carried out psychological study of professional activity of inspectors in the SSVI of EMERCOM of Russia revealed the professionally important qualities necessary for achieving professional goals. The findings are of great help in improving professional psychological selection and determining the degree of compliance of a candidate's psychological qualities with the requirements for the specialty.

\section{Keywords}

professionally important qualities, professional activity, inspector, psychodiagnostic study, psychodiagnostic tools, individual psychological characteristics, psychophysiological characteristics, professional success, expert survey, significance of differences

\section{Highlights}

- The study examined features of professional activities of inspectors in the SSVI of EMERCOM of Russia, and also the role of professionally important qualities in their activities.

- The expert survey revealed the psychological and psychophysiological professionally important qualities of inspectors in the SSVI of EMERCOM of Russia that could help in achieving professional goals.

- The expert survey and mathematical methods revealed the polar groups and also statistically significant differences between successful and unsuccessful inspectors in the SSVI of EMERCOM of Russia. This is sufficient to predict the professional success of inspectors in the SSVI of EMERCOM of Russia.

\section{For citation}

Shoigu Ju. S., Tarasova A. A. Professionally Important Qualities of Inspectors in the State Small Vessels Inspectorate of EMERCOM of Russia. Rossiiskii psikhologicheskii zhurnal Russian Psychological Journal, 2017, V. 14, no. 4, pp. 267-295 (in Russian).

Original manuscript received 01.12.2017 


\section{Введение}

Профессиональная деятельность занимает в жизни человека одно из важных мест. Труд является не только средством, обеспечивающим существование и жизнедеятельность, но и способом познания и преобразования окружающего мира, условием развития и формирования личности, целью, потребностью и смыслом жизни. Любая профессия накладывает отпечаток на личность человека, постепенно меняя его поведение в целом $[1,2,3]$. В настоящее время расширяется перечень профессий, предъявляющих к человеку значительные требования, которые связаны с чрезмерными интеллектуальными и психоэмоциональными нагрузками, с высокой вероятностью действия экстремальных факторов. К таким профессиям относится, в частности, профессия инспектора ГИМС МЧС России.

Инспектор - это лицо, занимающееся надзором, контролем, проверяющее соблюдение тех или иных правил и норм в пределах своей компетенции. Профессия инспектора ГИМС МЧС России возникла в связи с необходимостью обеспечения безопасности людей на водных объектах. Она относится к группе охранных профессий, не создающих материальные ценности, а сберегающие их. Инспектора имеют дело как с людьми, так и с материальными объектами. Исходя из распространенного деления профессий по системам взаимодействия «субъект - объект труда», профессию инспектора ГИМС МЧС России относят к профессиям, где взаимодействие происходит в системе «человек - среда - человек». Профессиональная деятельность инспекторов ГИМС МЧС России сопряжена с полифакторным стрессовым воздействием, обусловленным работой в сложных гидрометеорологических условиях (зачастую на территориях с ухудшением санитарно-эпидемиологической обстановки, в местах массового скопления людей), а также рядом психологических факторов, связанных с напряжением и угрозой собственной жизни и здоровью. Аварии и нарушения на водных объектах считаются одним из тяжелых бедствий, обстановка с ними постоянно ухудшается.

Также профессия инспектора ГИМС МЧС России требует от него участия в различных видах деятельности: операторской, документационной, контролирующей, организаторской, исследовательской, аналитической, консультативной, педагогической, коммуникативной, стимулирующей. Экстремальный характер профессии инспектора ГИМС МЧС России, многообразие выполняемых функций, значительные физические, нервно-психологические нагрузки при ликвидации аварий, катастроф и чрезвычайных ситуаций предъявляют повышенные требования не только к его профессиональным навыкам и уровню физического здоровья, но и к психологическим и психофизиологическим характеристикам, составляющим в совокупности комплекс индивидуально-психологических профессионально важных качеств, наличие и степень 
выраженности которых оказывает существенное влияние на эффективность деятельности. Стоит также отметить, что сочетание таких факторов, как редкость профессии в сфере государственной инспекции маломерных судов и отсутствие высших учебных заведений для подготовки специалистов по данному виду деятельности, достаточно сильно сказывается на профессионализме и психологической готовности к данному виду деятельности подбираемых кадров в ГИМС МЧС России. Все это, в свою очередь, обуславливает актуальность и практическую необходимость разработки мероприятий и средств психологического отбора данных специалистов, задачей которого и является определение долгосрочного прогноза успешной деятельности. Основу такого отбора составляют надежные, валидные и практичные психодиагностические методики, позволяющие оценить симптомокомплекс профессионально важных психологических качеств специалиста.

\section{Анализ литературы по тематике исследования}

Одна из самых главных особенностей человека заключается в том, что он, в отличие от животных, способен трудиться, а любой вид труда - это деятельность. Людям свойственны определенные виды деятельности, которые можно обнаружить практически у всех без исключения и которые соответствуют общим потребностям, а точнее - видам социальной человеческой активности. В эти виды активности неизбежно включается каждый человек в процессе своего индивидуального развития. Этапы психического развития человека характеризуются определенной ведущей деятельностью. Ведущая деятельность [4] - это такая деятельность, в форме которой возникают и внутри которой дифференцируются другие, новые виды деятельности; в которой формируются или перестраиваются частные психические процессы; от которой ближайшим образом зависят наблюдаемые в данный период развития основные психологические изменения. В зрелом возрасте ведущей деятельностью можно считать максимальную реализацию сущностных сил человека в ходе активного включения в производительную жизнь общества, вхождение в которую сопряжено с профессиональным становлением личности. С точки зрения Е.А. Климова, основным направлением развития человека как субъекта труда является становление его как личности, а также развитие его профессионально важных качеств, которые определяют возможность успешного выполнения той или иной профессиональной деятельности [5].

Общепризнанным является тот факт, что любая деятельность реализуется на базе системы профессионально важных качеств, представляющих собой набор своеобразных симптомокомплексов субъективных свойств, являющихся узловым моментом формирования психологической системы деятельности и выступающих в роли внутренних условий, через которые 
преломляются внешние воздействия и требования деятельности [6]. Так, Е.А. Климов, В.С. Мерлин, В.Д. Небылицын и Б. М. Теплов выделяют в структуре ПВК «индивидуальный стиль деятельности» - обусловленную типологическими особенностями устойчивую систему способов, которая складывается у человека, стремящегося к наилучшему выполнению возложенных на него обязанностей. В.Л. Марищук полагает, что ПВК представляют собой отдельные динамические черты личности, отдельные психические и психомоторные свойства (выражаемые уровнем развития соответствующих психических и психомоторных процессов), а также физические качества, соответствующие требованиям к человеку какой-либо определенной профессии и способствующие успешному овладению этой профессией [7]. Согласно Е.П. Ермолаевой, ПВК - психологический потенциал для формирования знаний, умений, навыков; знания, умения, навыки - необходимое условие и ресурс для формирования профессиональной компетенции [8]. Ю.В. Котелова рассматривает понятие «профессионально важных признаков» и предлагает отнести к ним психологические особенности сенсорной, мыслительной, моторной деятельностей, а также особенности внимания, мышления, памяти, эмоциональноволевой сферы и особенности личности [9]. А. В. Карпов дает следующее определение: «Профессионально важные качества - это индивидуальные свойства субъекта деятельности, которые необходимы и достаточны для ее реализации на нормативно заданном уровне и которые значимо и положительно коррелируют хотя бы с одним (или несколькими) ее основными результативными параметрами - качеством, производительностью, надежностью» $[10$, с. 243].

Однако необходимо упомянуть, что одним из первых факторов, на который стараются обращать внимание при изучении психологических особенностей профессии, является психомоторика, т. к. во всякую деятельность включена система действий. В связи с этим, А.Н. Леонтьев в своей теории деятельности указывал, что человеческая деятельность не существует иначе, как в форме действия или цепи действий, причем единицы анализа деятельностного подхода имеют четко очерченный психологический смысл: деятельность рассматривается как сложная динамическая, многоуровневая система, состоящая из социально-психологического, психологического и психофизиологического уровней, которые могут изменяться в процессе деятельности [4]. В связи с этим, профессиональную деятельность необходимо изучать как целостную динамическую систему субъект-объектных взаимосвязей, обусловленных, с одной стороны, мотивационно-потребностной сферой индивида, его профессиональной подготовленностью, его психофизиологическими возможностями, а с другой стороны - заданными нормативными условиями исполнения деятельности. Данные положения 
лежат в основе профессионально-психологического отбора (далее - ППО), который должен базироваться на концепции социально-психологической адаптации и способностей личности, системогенеза, теории функциональных состояний и теории адаптации, личностно-деятельностном подходе [11].

В настоящее время ППО широко применяется в силовых ведомствах Российской Федерации. Ведущий принцип ППО - комплексность, которая определяется многообразием целей и задач, а также сложностью структуры профессиональных способностей. Отбор сотрудников силовых ведомств РФ базируется на всестороннем изучении личности кандидатов, а решение об их профессиональной пригодности выносится с учетом совокупности физических, физиологических, психологических характеристик, а также состояния здоровья и мотивации. Максимальный опыт практического применения ППО был накоплен в психофизиологических лабораториях авиационных и военно-морских училищ Вооруженных сил, т. е., с одной стороны, в тех специальностях, где подготовка каждого специалиста требует больших экономических вложений, и, с другой стороны, в тех специальностях, где ошибка специалиста может повлечь за собой большие материальные и человеческие потери [12].

Также были разработаны методические средства, позволяющие изучать профессии и группы профессий с точки зрения тех требований, которые профессия предъявляет к человеку, и тех условий, которые она предоставляет для выполнения профессиональных обязанностей $[13,14,15,16,17]$. В настоящее время в силовых ведомствах РФ в процессе психологического обследования проводится комплексное обследование с применением психологических и психофизиологических методик, определяющих соответствие уровня развития индивидуальных психологических и психофизиологических качеств кандидатов профессиональным требованиям, осуществляющих прогноз успешности освоения профессии, эффективность осуществления служебной деятельности или работы.

Применительно к МЧС России профессиональный психологический отбор понимается как «комплекс психодиагностических мероприятий, направленных на выявление психологических, социально-психологических и психофизиологических особенностей кандидатов, оценку уровня развития индивидуально-психологических профессионально важных качеств, определение степени пригодности кандидата к выполнению профессиональных обязанностей или обучению по конкретной специальности» [18, с. 168].

Однако, для оценки уровня сформированности профессионально важных психологических качеств будущих спасателей - курсантов вузов МЧС России необходимо использовать комплекс валидных психодиагностических средств. В частности, такой комплекс был разработан в работах Ю.С. Шойгу [19]. 
На основе результатов экспериментальных исследований, проведенных Ю.С. Шойгу, определены информативные психодиагностические показатели для оценки профессиональной пригодности, прогноза успешности профессиональной подготовки и эффективности последующей профессиональной деятельности будущих спасателей МЧС России.

В связи с описанным экстремальным характером профессии инспекторов ГИМС МЧС России обнаруживается необходимость разработки мероприятий и средств психологического отбора данных специалистов. Специалисты ГИМС МЧС России решают широкий круг проблем, связанных с осуществлением многих социальных функций. Это предъявляет высокие требования не только к профессиональным знаниям и умениям, но и к личности специалистов ГИМС МЧС России. Таким образом, можно говорить о том, что разработка научно-обоснованных рекомендаций по профессиональному психологическому отбору специалистов ГИМС МЧС России представляет научный и практический интерес. Это подтверждает важность психологического изучения профессиональной деятельности инспекторов ГИМС МЧС России, которое позволяет выявить необходимые требования к психофизиологическим и личностным характеристикам человека, определить всю совокупность профессионально важных качеств.

Реализация такого мероприятия, как профессиональный психологический отбор, невозможна без оценки таких составляющих, как ПВК.

Существует две важнейшие категории ПВК. Во-первых, ПВК, которые характеризуются наибольшей непосредственной связью с параметрами деятельности. Они обозначаются понятием ведущих ПВК. Во-вторых, те ПВК, которые имеют наибольшее число внутрисистемных связей с другими качествами, т. е. характеризуются наибольшим структурным весом и, следовательно, занимают центральное место во всей системе качеств. Они обозначаются понятием базовых ПВК. Эти качества могут не коррелировать значимо с параметрами деятельности, однако они не менее, а часто - более - важны для ее реализации. Именно ПВК, по мнению А.В. Карпова, являются основой для формирования подсистем ПВК в целом, вокруг них и на их базе объединяются и сорганизуются все иные качества субъекта, необходимые для обеспечения деятельности и (или) ее основных действий, функций [10]. Поэтому ПВК являются структурообразующим основанием для той или иной деятельности.

Проблема ПВК личности специалиста рассматривается в психологии в связи с вопросами прогнозирования его пригодности (успешности) на основе выраженности ПВК, т. е. выраженность ПВК рассматривается как один из факторов, влияющих на профессиональную успешность. В свою очередь, успешность деятельности - характеристика деятельности, включающая в себя 


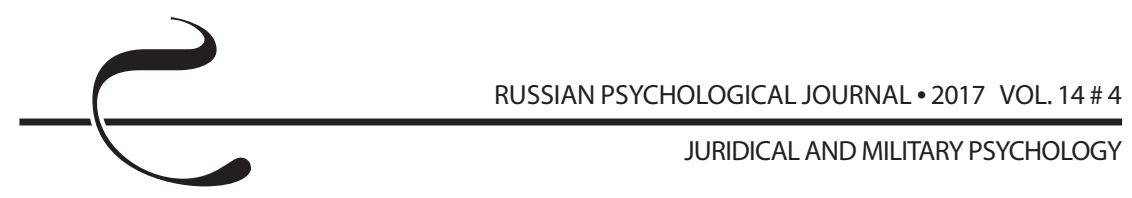

производительность труда, качество продукции, скорость, безошибочность трудовых действий и т. д. При оценке успешности деятельности следует учитывать также физиологические затраты, которые необходимы для решения профессиональной задачи. Успешность деятельности тесно связана с интеллектуальной, мотивационной и эмоционально-волевой сферами личности, а также зависит от индивидуальных психофизиологических качеств. Основываясь на отечественном и зарубежном опыте отбора специалистов, М.Г. Дебольский выделяет несколько ограничений прогнозирования успешности профессиональной деятельности на основе ПВК: а) личностные качества взаимосвязаны, б) с течением времени личность изменяется, в) с течением времени могут изменяться требования к профессии, а, следовательно, к личности специалиста [2].

Профессионально важные качества специалиста являются существенным фактором его профессиональной компетентности. Уровень сформированности данного профессионального конструкта помимо успешности деятельности определяет еще и адекватность функционирования личности профессионала, как в соответствующей профессиональной среде, так и в обществе в целом. Потенциально широкий спектр ПВК, который должны адекватно отражать особенности поведения, мышления и социализации личности в соответствующей профессиональной деятельности, обуславливает необходимость оценки необходимых ПВК, в том числе и в рамках процедуры психологического отбора $[6,15,20,21,22,23]$. В свою очередь, необходимые психические свойства человека развиваются в процессе его профессиональной деятельности или компенсируются другими свойствами с помощью специальных приемов и способов действий. Лишь в экстремальных и чрезвычайных ситуациях требования к отдельным психическим свойствам резко повышаются, в то же время многие механизмы компенсации не срабатывают. И если профессиональная деятельность такова, что экстремальные ситуации возникают в ней довольно часто, появляется необходимость в отсеве людей, не соответствующих по психологическим свойствам требованиям деятельности, или в перераспределении их по рабочим местам с учетом индивидуальных психологических предпосылок.

Что касается сотрудников МЧС, то они должны обладать такими способностями и качествами: ответственностью, смелостью, эмоциональной устойчивостью, решительностью, твердым характером и силой воли. Эмоциональная устойчивость позволяет сотруднику МЧС сохранять необходимую физическую и психическую работоспособность во время ЧС. Кроме того, эмоционально устойчивые сотрудники более эффективно справляются со стрессом, уверенно и хладнокровно применяют усвоенные навыки. Устойчивые к стрессу люди характеризуются как неимпульсивные, 
активные, настойчивые в преодолении любых трудностей. Также важную роль в профессиональной деятельности сотрудника МЧС играет самооценка, причем ее неадекватность уменьшает надежность работы в экстремальных условиях. К тому же для сотрудника МЧС достаточно важную роль играют особенности нейродинамики и индивидуально-типологические свойства. Было установлено, что люди с сильной нервной системой со стороны возбуждения имеют большую склонность к напряженной деятельности, чем лица со слабой нервной системой, для которых характерны более высокая тревожность и, соответственно, более низкая самооценка. В части, касающейся требований, предъявляемых к качествам инспектора ГИМС МЧС России, специалисты, имеющие значительный опыт успешной работы и знания в этой области профессиональной деятельности, выделяют такие качества, как: стрессоустойчивость, коммуникабельность, наличие лидерских и организационных качеств, стремление к достижению успеха, способность к переключению с одного типа заданий на другой в условиях дефицита времени, развитые свойства внимания и памяти.

Вследствие чего, структура ПВК - это сложное и внутренне дифференцированное системное образование, которое детерминирует успешность освоения и выполнения трудовой деятельности. При этом любая деятельность реализуется на базе системы ПВК, представляющей собой набор своеобразных симптомокомплексов субъективных свойств, специфических для той или иной профессиональной деятельности. Симптомокомплексы формируются у субъекта в ходе освоения им соответствующей деятельности и содержат в себе специфические подсистемы ПВК, обеспечивающие выполнение каждого очередного этапа профессиональной деятельности: формирование вектора «мотив - цель», планирование деятельности, переработку текущей информации, концептуальную модель, принятие решения, действия, проверку результатов, коррекцию действий $[24,25,26]$.

Следовательно, возросшая интенсивность, интеллектуальность, эмоциональная напряженность труда специалистов ГИМС МЧС России с одной стороны, требования эффективного функционирования структуры организации, грамотного отбора и расстановки кадров, создания эффективных команд, с другой стороны, приводят к необходимости создания системы ПВК для данного контингента профессионалов для проведения более успешного профессионально-психологического отбора сотрудников.

Таким образом, целью исследования явилось выделение совокупности профессионально важных качеств инспектора ГИМС МЧС России, обеспечивающих успешность деятельности, что, в свою очередь, стало определением степени пригодности кандидатов к выполнению профессиональных обязанностей. 


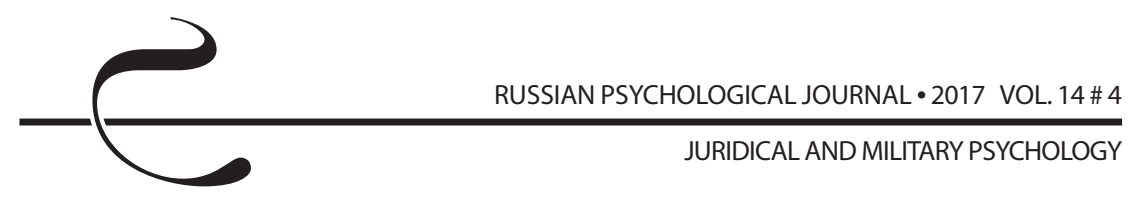

\section{Методы}

Основу работы составили исследования, проведенные в период февраль - апрель 2011 г. Было обследовано 275 человек из числа инспекторов ГИМС МЧС России по субъектам Российской Федерации. Средний возраст обследуемых составил $42 \pm 11$ лет. Критерием включения в группу был стаж работы по специальности не менее 3-х лет. Критерием исключения из группы было наличие клинически выраженных акцентуаций в профиле методики многостороннего исследования личности (по Ф.Б. Березину), недостоверных результатов по методикам личностного блока, а также значения средней арифметической (М), превышающего $\pm 3 \sigma$.

Для решения задачи по выделению ПВК инспектора ГИМС МЧС России исследование было организовано в три этапа. На первом этапе проводилась серия экспертных опросов по определению индивидуально-психологических и психофизиологических ПВК, необходимых, по мнению экспертов, для успешного выполнения профессиональной деятельности инспектора ГИМС МЧС России. Прогнозирование успешности профессиональной деятельности в области ликвидации последствий чрезвычайных ситуаций зависит не только от общей и специальной подготовки специалиста, но и от степени развития у него ряда профессионально значимых качеств (индивидуально-личностных особенностей, характеристик эмоциональной устойчивости, особенностей интеллектуальной и мотивационной сфер, показателей внимания, памяти, сенсомоторных функций и т. д.). При этом объективность психодиагностических мероприятий во многом определяется достоверностью измерительных средств и технологий. Качественный состав экспертов определялся их профессиональными и личностными качествами: высокой профессиональной компетентностью, знанием специфических особенностей специальности, высокой позитивной мотивацией на проведение экспертизы [27, 28, 29]. Эксперты из числа руководящего состава работали с составленными опросными листами, оценивая выбранные ими в качестве ПВК индивидуально-психологические и психофизиологические характеристики по необходимой, на их взгляд, степени выраженности. При составлении перечня индивидуально-психологических и психофизиологических свойств учитывались особенности деятельности и требования, предъявляемые к качествам инспектора ГИМС МЧС России. Данные качества были обнаружены в процессе анализа служебной литературы, регламентирующей деятельность, в ходе бесед с компетентными специалистами, а также из наблюдения за выполнением ими трудовых операций. Формулировка характеристик (определений) тех или иных качеств составлялась таким образом, чтобы удовлетворять требованиям доступности и лаконичности. В результате проведенного интервьюирования экспертами был выделен 
перечень индивидуально-психологических и психофизиологических качеств инспектора ГИМС МЧС России, способствующих эффективному осуществлению профессиональной деятельности, а также ряд качеств, препятствующих ее успешному выполнению. Группу экспертов в количестве 40 человек составили начальники различных структурных подразделений, отделений, участков ГИМС МЧС России, имеющие стаж работы по специальности 10 лет и выше. Полученные данные представлены в таблице 1.

Таблица 1. ИнАивиАуально-психологические и психофризиологические ПВК инспектора ГИМС МЧС России по результатам усредненных экспертных оцеHOK $(n=40)$

Table 1. Psychological and psychophysiological professionally important qualities of inspectors in the SSVI of EMERCOM of Russia (average expert ratings, $n=40$ )

\begin{tabular}{|c|c|c|}
\hline № & $\begin{array}{c}\text { ПВК } \\
\text { Professionally important qualities }\end{array}$ & $\begin{array}{c}\text { Анти-ПВК } \\
\text { Anti-professionally important } \\
\text { qualities }\end{array}$ \\
\hline 1 & $\begin{array}{l}\text { Уровень развития базового интел- } \\
\text { ^екта выше срелних значений } \\
\text { Above average levels of basic } \\
\text { intelligence }\end{array}$ & $\begin{array}{l}\text { Низкий уровень развития базо- } \\
\text { вого интеллекта } \\
\text { Low levels of basic intelligence }\end{array}$ \\
\hline 2 & $\begin{array}{l}\text { Интел^ектуальная ^абильность } \\
\text { выше срелнего } \\
\text { Above average levels of intellectual } \\
\text { lability }\end{array}$ & $\begin{array}{l}\text { Низкая интеллектуальная } \\
\text { ^абильность } \\
\text { Low intellectual lability }\end{array}$ \\
\hline 3 & $\begin{array}{l}\text { Реалистический способ мышления } \\
\text { Realistic way of thinking }\end{array}$ & $\begin{array}{l}\text { ИАеалистический способ } \\
\text { мышления } \\
\text { Idealistic way of thinking }\end{array}$ \\
\hline 4 & $\begin{array}{l}\text { Равновыраженность аналитическо- } \\
\text { го, синтетического и прагматиче- } \\
\text { ского способов мышления } \\
\text { Equal skills in analytical, synthetical, } \\
\text { and pragmatic thinking }\end{array}$ & $\begin{array}{l}\text { Низкий уровень развития } \\
\text { свойств внимания } \\
\text { Low levels of attention properties }\end{array}$ \\
\hline
\end{tabular}




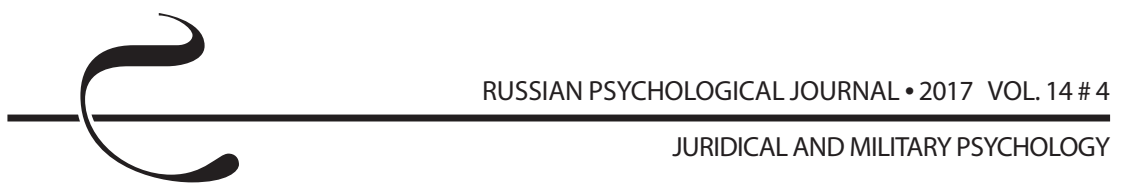

\begin{tabular}{|c|c|c|}
\hline 5 & $\begin{array}{l}\text { Развитые свойства внимания (объ- } \\
\text { ем, распределение, концентрация, } \\
\text { переключение, избирательность, } \\
\text { устойчивость)* } \\
\text { * в порядке убывания степени зна- } \\
\text { чимости свойств } \\
\text { Well-developed attention properties } \\
\text { (capacity, distribution, concentration, } \\
\text { switch, selectivity, and stability)* } \\
\text { * in descending order of importance }\end{array}$ & $\begin{array}{l}\text { Низкий уровень развития кратко- } \\
\text { временной, Аолговременной } \\
\text { и оперативной видов памяти } \\
\text { Low levels of short-term, long- } \\
\text { term, and working memory }\end{array}$ \\
\hline 6 & $\begin{array}{l}\text { Развитые кратковременная, Аолго- } \\
\text { временная и оперативная виды } \\
\text { памяти } \\
\text { Well-developed short-term, long-term, } \\
\text { and working memory }\end{array}$ & $\begin{array}{l}\text { Акцентуированная ^ичность; } \\
\text { ^ичность с клинически выра- } \\
\text { женными характерологически- } \\
\text { ми чертами } \\
\text { Accentuated personality; person- } \\
\text { ality with clinically pronounced } \\
\text { characterological traits }\end{array}$ \\
\hline 7 & $\begin{array}{l}\text { Гармонично развитая личность } \\
\text { (психическая норма) } \\
\text { Harmonious personality (mental } \\
\text { norm) }\end{array}$ & $\begin{array}{l}\text { Низкий уровень развития комму- } \\
\text { никативных и организаторских } \\
\text { ск^онностей } \\
\text { Low levels of communicative and } \\
\text { organizational aptitudes }\end{array}$ \\
\hline 8 & $\begin{array}{l}\text { Развитые коммуникативные и орга- } \\
\text { низаторские ск^онности } \\
\text { Well-developed communicative and } \\
\text { organizational aptitudes }\end{array}$ & $\begin{array}{l}\text { Низкий уровень нервно-психиче- } \\
\text { ской устойчивости } \\
\text { Low levels of neuropsychic } \\
\text { stability }\end{array}$ \\
\hline 9 & $\begin{array}{l}\text { Высокий уровень нервно-психиче- } \\
\text { ской устойчивости } \\
\text { High levels of neuropsychic stability }\end{array}$ & $\begin{array}{l}\text { Высокий уровень ^ичностной } \\
\text { тревожности } \\
\text { High levels of personal anxiety }\end{array}$ \\
\hline 10 & $\begin{array}{l}\text { Низкий уровень личностной } \\
\text { тревожности } \\
\text { Low levels of personal anxiety }\end{array}$ & $\begin{array}{l}\text { Мотивация на избегание } \\
\text { Avoidance motivation }\end{array}$ \\
\hline 11 & $\begin{array}{l}\text { Мотивация на Аостижение } \\
\text { Achievement motivation }\end{array}$ & $\begin{array}{l}\text { Экстернальный ^окус контроля } \\
\text { External locus of control }\end{array}$ \\
\hline 12 & $\begin{array}{l}\text { Интернальный ^окус контроля } \\
\text { Internal locus of control }\end{array}$ & \\
\hline 13 & $\begin{array}{l}\text { Развитые ^илерские качества } \\
\text { Well-developed leadership qualities }\end{array}$ & \\
\hline
\end{tabular}


Выявленные с помощью экспертных оценок ПВК в дальнейшем уточнялись и дополнялись результатами, полученными при применении других методов исследования психофизиологических и личностных свойств.

На втором этапе осуществлялся подбор психодиагностического инструментария, который прошел массовую апробацию и доказал свою практическую ценность с точки зрения прогностичности и валидности результатов. Данный психодиагностический инструментарий позволил провести обследование инспекторов ГИМС МЧС России с целью определения у них наличия и степени выраженности индивидуально-психологических и психофизиологических характеристик, выделенных экспертами в качестве ПВК.

Полученные результаты обследования подвергались первичной математической обработке. В дальнейшем, с помощью программы IBM SPSS Statistics Version 17, был проведен статистический анализ полученных итоговых данных, в результате чего были произведены расчеты средней арифметической (M), среднего квадратичного отклонения (б), ошибки средней арифметической (m).

На третьем этапе был проведена вторая серия экспертных опросов с целью оценки эффективности деятельности инспекторов ГИМС МЧС России, прошедших психодиагностическое обследование. Это позволило разбить генеральную совокупность выборки на группы успешных, неуспешных и «средних» специалистов, после чего они подверглись статистической обработке на предмет выявления значимых различий.

\section{Результаты}

При решении задач выявления различий мы исходили из того, что «средние» («норма» по популяции) рассматриваются как исследовательский результат, который позволяет сформировать предположение о том, что существуют различия между успешными и неуспешными специалистами. То есть у успешных специалистов могут не наблюдаться «средние» значения по исследуемым показателям, а также наличие в профессиональной деятельности собственного индивидуального стиля (в том числе зависящего от индивидуально-личностных и психофизиологических характеристик) важнее соответствия «среднегрупповому» профилю. У каждого успешного специалиста его психологические свойства создают неповторимый комплекс качеств, который при усреднении данных теряется. Для подтверждения предположения о том, что существуют различия между успешными и неуспешными специалистами, вначале было проведено сравнение на выявление значимых различий между успешными и «средними» специалистами с помощью непараметрического математического критерия «U-критерий Манна - Уитни», который предназначен для сопоставления показателей, измеренных в одних и тех же условиях на двух выборках обследуемых. Достоверным считался 
уровень асимптотической значимости $p<0,05$, свидетельствующий о том, что вероятность того, что статистическая значимость различий случайна, не более $5 \%$ [30]. Результаты сравнения представлены в таблице 2.

Таблица 2. Аостоверность различий межАу успешными и «среАними» специалистами

Table 2. Significance of differences between successful and "average" professionals

\begin{tabular}{|c|c|c|c|c|c|}
\hline \multirow{2}{*}{ 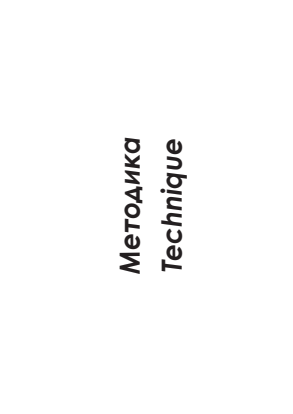 } & \multirow{2}{*}{ 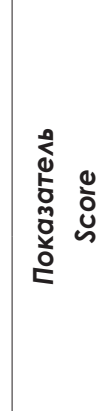 } & \multirow{2}{*}{ 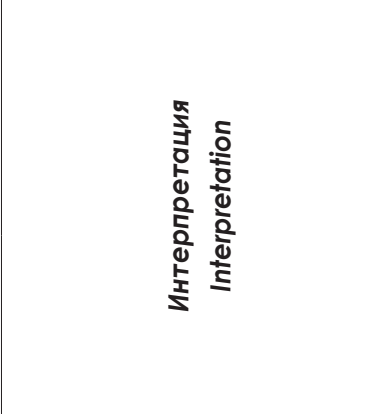 } & \multirow{2}{*}{ 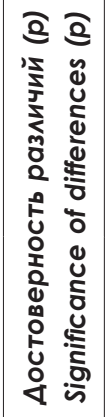 } & \multicolumn{2}{|c|}{ 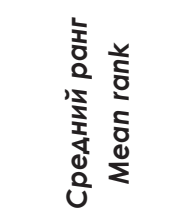 } \\
\hline & & & & 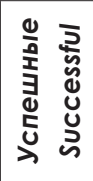 & 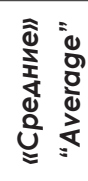 \\
\hline $\begin{array}{l}\text { «Тст возрастающей } \\
\text { трудности А. Равена» } \\
30 \text { заланий }(1,2 \\
\text { варианты) }\end{array}$ & иб & $\begin{array}{l}\text { Уровень развития базового } \\
\text { интеммекта }\end{array}$ & 0,399 & 91,24 & 98,16 \\
\hline $\begin{array}{l}\text { «Интелмектуальная } \\
\text { ^абильносты» }\end{array}$ & И^ & $\begin{array}{l}\text { Уровень интеллектуальной } \\
\text { ^абильности, характе- } \\
\text { ризующей ^абильность } \\
\text { мышления, скорость пере- } \\
\text { ключения мыслительных } \\
\text { процессов }\end{array}$ & 0,433 & 91,55 & 97,97 \\
\hline \multirow{5}{*}{$\begin{array}{l}\text { «Ттиль мышле- } \\
\text { ния», в алаптации } \\
\text { А. А^ексеева, } \\
\text { ^. Громовой }\end{array}$} & $M c$ & $\begin{array}{l}\text { Синтетический стиль } \\
\text { мышления }\end{array}$ & 0,734 & 97,21 & 94,43 \\
\hline & Mи & $\begin{array}{l}\text { ИАеалистический стиль } \\
\text { мышления }\end{array}$ & 0,549 & 98,52 & 93,62 \\
\hline & Мп & $\begin{array}{l}\text { Прагматический стиль } \\
\text { мышления }\end{array}$ & 0,059 & 85,97 & 101,45 \\
\hline & $\mathrm{Ma}$ & $\begin{array}{l}\text { Аналитический стиль } \\
\text { мышления }\end{array}$ & 0,725 & 97,27 & 94,39 \\
\hline & $M p$ & $\begin{array}{l}\text { Реалистический стиль } \\
\text { мышления }\end{array}$ & 0,584 & 98,26 & 93,78 \\
\hline
\end{tabular}




\begin{tabular}{|c|c|c|c|c|c|}
\hline \multirow{2}{*}{ 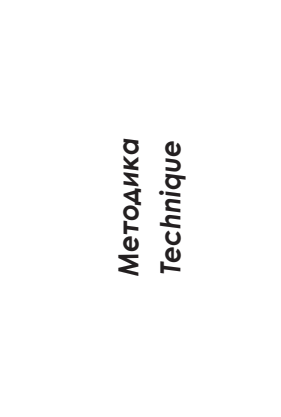 } & \multirow{2}{*}{ 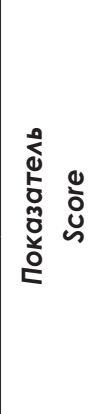 } & \multirow{2}{*}{ 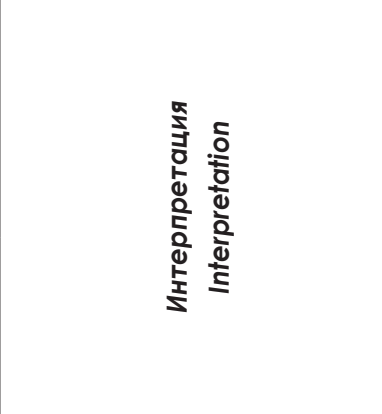 } & \multirow{2}{*}{ 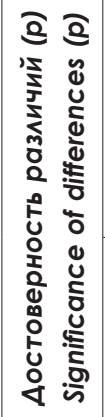 } & \multicolumn{2}{|c|}{ 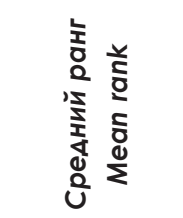 } \\
\hline & & & & 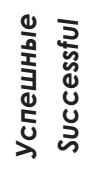 & 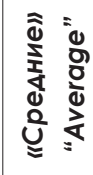 \\
\hline \multirow{4}{*}{ «Кольца ^анАОАьта» } & $\mathrm{V}_{\text {BH }}$ & Объем внимания & 0,698 & 97,46 & 94,28 \\
\hline & $\mathrm{KBH}$ & Концентрация внимания & 0,107 & 103,62 & 90,44 \\
\hline & Ивн & Избирательность внимания & 0,098 & 103,84 & 90,30 \\
\hline & $\mathrm{У}_{\text {вн }}$ & Устойчивость внимания & 0,339 & 99,79 & 91,98 \\
\hline \multirow{2}{*}{ «Числовой кваАрат» } & $\mathrm{V}_{\text {BH }}$ & Объем внимания & 0,358 & 98,49 & 91,13 \\
\hline & PBH & Распределение внимания & 0,210 & 100,14 & 90,07 \\
\hline \multirow{2}{*}{$\begin{array}{l}\text { «роба } \\
\text { Мюнстерберга» }\end{array}$} & $\mathrm{V}_{\text {BH }}$ & Объем внимания & 0,016 & 107,60 & 87,95 \\
\hline & Ивн & Избирательность внимания & 0,033 & 106,23 & 88,80 \\
\hline $\begin{array}{l}\text { «Оперативная } \\
\text { памяты» }\end{array}$ & Оп & Оперативная память & 0,037 & 101,58 & 84,55 \\
\hline \multirow{5}{*}{$\begin{array}{l}\text { «Запоминание } 10 \\
\text { слов» }\end{array}$} & КП। & $\begin{array}{l}\text { Кратковременная память } \\
\text { (1 повторение) }\end{array}$ & 0,903 & 94,90 & 95,87 \\
\hline & КП2 & $\begin{array}{l}\text { Кратковременная память } \\
\text { (2 повторение) }\end{array}$ & 0,832 & 94,47 & 96,14 \\
\hline & КПЗ & $\begin{array}{l}\text { Кратковременная память } \\
\text { (3 повторение) }\end{array}$ & 0,964 & 95,29 & 95,63 \\
\hline & КП4 & $\begin{array}{l}\text { Кратковременная память } \\
\text { (4 повторение) }\end{array}$ & 0,457 & 92,14 & 97,60 \\
\hline & $\Delta \Pi$ & Аолговременная память & 0,478 & 98,90 & 93,38 \\
\hline \multirow{2}{*}{$\begin{array}{l}\text { «Оценка комму- } \\
\text { никативных и ор- } \\
\text { ганизаторских } \\
\text { ск^онностей» }\end{array}$} & KC & $\begin{array}{l}\text { Коммуникативные } \\
\text { скАонности }\end{array}$ & 0,821 & 96,64 & 94,79 \\
\hline & OC & $\begin{array}{l}\text { Организаторские } \\
\text { ск^онности }\end{array}$ & 0,588 & 98,22 & 93,80 \\
\hline
\end{tabular}




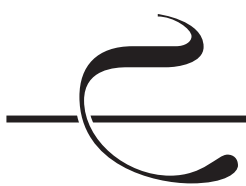

\begin{tabular}{|c|c|c|c|c|c|}
\hline \multirow{2}{*}{ 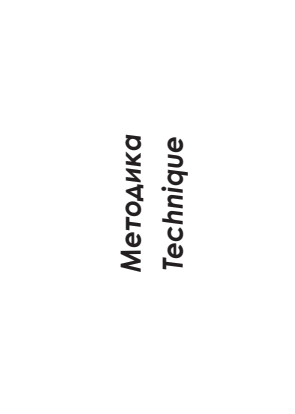 } & \multirow{2}{*}{ 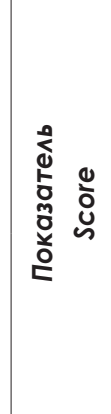 } & \multirow{2}{*}{ 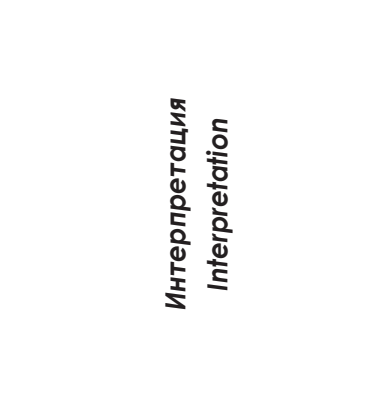 } & \multirow{2}{*}{ 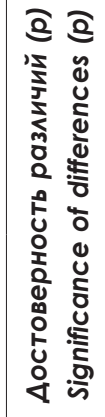 } & \multicolumn{2}{|c|}{ 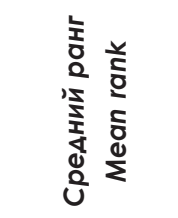 } \\
\hline & & & & 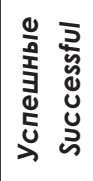 & 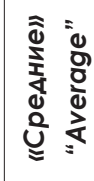 \\
\hline $\begin{array}{l}\text { «Оценка уров- } \\
\text { ня субъективного } \\
\text { контроля» }\end{array}$ & YCK & $\begin{array}{l}\text { Уровень субъективного } \\
\text { контроля }\end{array}$ & 0,859 & 94,60 & 96,06 \\
\hline «Прогноз» & НПУ & $\begin{array}{l}\text { Нервно-психическая } \\
\text { устойчивость }\end{array}$ & 0,486 & 90,49 & 96,15 \\
\hline $\begin{array}{l}\text { «Аиагностика Аич- } \\
\text { ностной и реактив- } \\
\text { ной тревожности } \\
\text { ч. Спилбергера, } \\
\text { Ю. Ханина»в части, } \\
\text { касающейся ^ич- } \\
\text { ностной тревожности }\end{array}$ & $\wedge \top$ & Аичностная тревожность & 0,292 & 90,19 & 98,81 \\
\hline & $\mathrm{HC}$ & Направленность на себя & 0,552 & 96,49 & 91,66 \\
\hline $\begin{array}{l}\text { Ориентировочная } \\
\text { анкета }\end{array}$ & BA & $\begin{array}{l}\text { Направленность на } \\
\text { взаимолействие }\end{array}$ & 0,700 & 95,43 & 92,31 \\
\hline & H3 & Направленность на залачу & 0,289 & 88,19 & 96,78 \\
\hline $\begin{array}{l}\text { «АиАерский } \\
\text { потенциал» }\end{array}$ & $\wedge П$ & $\begin{array}{l}\text { АиАерский потенциал, про- } \\
\text { явление ^илерских качеств }\end{array}$ & 0,802 & 94,26 & 96,27 \\
\hline $\begin{array}{l}\text { «Моторная проба } \\
\text { Шварцландера» }\end{array}$ & Ц० & $\begin{array}{l}\text { ААекватность уровня при- } \\
\text { тязаний, предпочитаемый } \\
\text { уровень риска }\end{array}$ & 0,031 & 84,25 & 101,77 \\
\hline
\end{tabular}




\begin{tabular}{|c|c|c|c|c|c|}
\hline \multirow{2}{*}{ 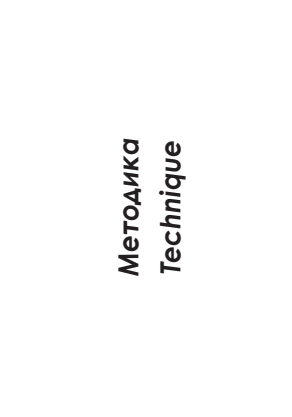 } & \multirow{2}{*}{ 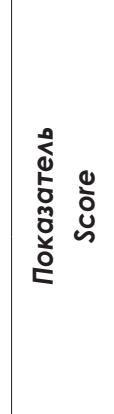 } & \multirow{2}{*}{ 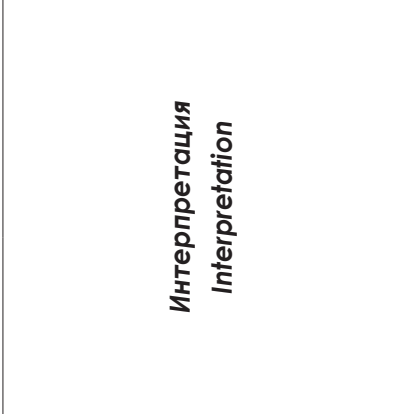 } & \multirow{2}{*}{ 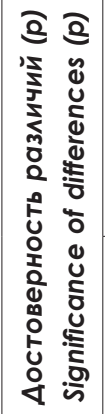 } & \multicolumn{2}{|c|}{ 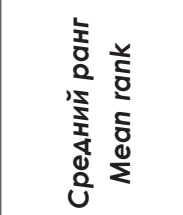 } \\
\hline & & & & 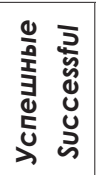 & 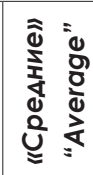 \\
\hline \multirow{16}{*}{$\begin{array}{l}\text { «16-фракторный ^ич- } \\
\text { ностный опросник } \\
\text { Кеттем^а» (фрорма А) }\end{array}$} & क. A & Афрфректомия - шизотимия & 0,057 & 85,42 & 100,89 \\
\hline & фp. B & $\begin{array}{l}\text { Высокий интеллект - низкий } \\
\text { интеллект (абстрактное } \\
\text { мышление, высокая спо- } \\
\text { собность к обучаемости) }\end{array}$ & 0,839 & 96,02 & 94,37 \\
\hline & op. C & $\begin{array}{l}\text { Эмоциональная устойчи- } \\
\text { вость - эмоциональная } \\
\text { неустойчивость }\end{array}$ & 0,903 & 95,62 & 94,62 \\
\hline & фp. E & $\begin{array}{l}\text { АОмИнантнОСть - КОН- } \\
\text { фоормность }\end{array}$ & 0,963 & 94,76 & 95,15 \\
\hline & dp. F & Беспечность - скованность & 0,373 & 90,50 & 97,77 \\
\hline & dp. G & $\begin{array}{l}\text { СовестАивость - НеАобро- } \\
\text { совестность }\end{array}$ & 0,095 & 103,42 & 89,82 \\
\hline & क. $\mathrm{H}$ & Сме^ость - робость & 0,800 & 96,28 & 94,21 \\
\hline & dp. I & Сензитивность - суровость & 0,767 & 93,51 & 95,92 \\
\hline & कp. L & $\begin{array}{l}\text { ПоАОзрительнОСть - АОвер- } \\
\text { чивость }\end{array}$ & 0,493 & 91,55 & 97,12 \\
\hline & dp. M & $\begin{array}{l}\text { Мечтательность - практич- } \\
\text { ность }\end{array}$ & 0,810 & 93,79 & 95,74 \\
\hline & dp. N & $\begin{array}{l}\text { Проницательность - наи- } \\
\text { вность }\end{array}$ & 0,009 & 108,22 & 86,86 \\
\hline & dp. $\bigcirc$ & $\begin{array}{l}\text { Ск^онность К чувству } \\
\text { вины - самоуверенность }\end{array}$ & 0,922 & 94,51 & 95,30 \\
\hline & कp. Q1 & Гибкость - риГиАНОСть & 0,292 & 89,69 & 98,26 \\
\hline & op. Q2 & $\begin{array}{l}\text { Самостоятельность - зави- } \\
\text { симость от группы }\end{array}$ & 0,322 & 99,99 & 91,93 \\
\hline & dp. Q3 & $\begin{array}{l}\text { ВысоКий самоКонтроль } \\
\text { поведения - низкий само- } \\
\text { контроль повеАения }\end{array}$ & 0,695 & 96,98 & 93,78 \\
\hline & фp. Q4 & $\begin{array}{l}\text { Напряженность - рассла- } \\
\text { бленность }\end{array}$ & 0,305 & 89,81 & 98,19 \\
\hline
\end{tabular}




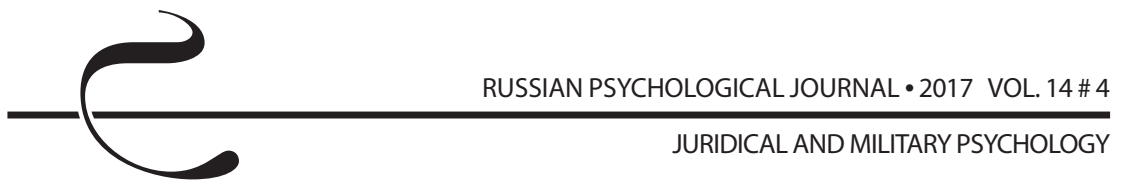

\begin{tabular}{|c|c|c|c|c|c|}
\hline \multirow{2}{*}{ 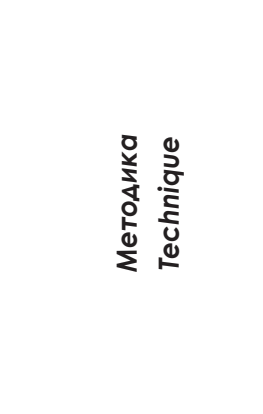 } & \multirow{2}{*}{ 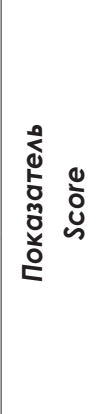 } & \multirow{2}{*}{ 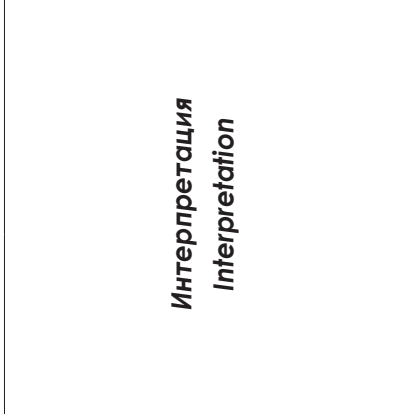 } & \multirow{2}{*}{ 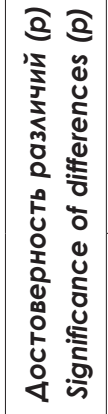 } & \multicolumn{2}{|c|}{ 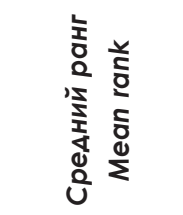 } \\
\hline & & & & 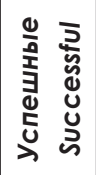 & 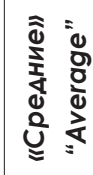 \\
\hline \multirow{13}{*}{$\begin{array}{l}\text { Методика много- } \\
\text { стороннего иссле- } \\
\text { Аования ^ичности } \\
\text { (по Ф.Б. Березину) }\end{array}$} & L & $\begin{array}{l}\text { Шкала социальной } \\
\text { желательности }\end{array}$ & 0,256 & 98,31 & 89,17 \\
\hline & $\mathrm{F}$ & Шка^а Аостоверности & 0,090 & 83,75 & 97,51 \\
\hline & K & Шкала коррекции & 0,499 & 96,48 & 90,98 \\
\hline & $\begin{array}{l}1 \text { шKa- } \\
\wedge a \\
(H s)\end{array}$ & Соматизация тревоги & 0,067 & 101,92 & 87,11 \\
\hline & $\begin{array}{l}2 \text { ШKa- } \\
\wedge a(D) \\
\end{array}$ & $\begin{array}{l}\text { Тревога и Аепрессивные } \\
\text { тенденции }\end{array}$ & 0,881 & 91,72 & 92,94 \\
\hline & $\begin{array}{l}\begin{array}{l}\text { шKa- } \\
\wedge a \\
\text { (Hy) }\end{array} \\
\end{array}$ & $\begin{array}{l}\text { Вытеснение фракторов, вы- } \\
\text { зывающих тревогу }\end{array}$ & 0,070 & 101,87 & 87,14 \\
\hline & $\begin{array}{l}4 \text { шKa- } \\
\wedge \mathrm{a} \\
(\mathrm{Pd}) \\
\end{array}$ & $\begin{array}{l}\text { Реализация эмоциональ- } \\
\text { ной напряженности в непо- } \\
\text { средственном поведении }\end{array}$ & 0,309 & 87,25 & 95,51 \\
\hline & $\begin{array}{l}5 \text { шKa- } \\
\wedge a \\
\text { (Mf) } \\
\end{array}$ & $\begin{array}{l}\text { Выраженность мужских } \\
\text { и женских черт характера }\end{array}$ & 0,807 & 93,76 & 91,78 \\
\hline & $\begin{array}{l}6 \text { ШKa- } \\
\wedge a \\
(\mathrm{~Pa}) \\
\end{array}$ & РигиАность афроректа & 0,902 & 93,13 & 92,14 \\
\hline & $\begin{array}{l}7 \text { шка- } \\
\wedge a(\mathrm{Pt}) \\
\end{array}$ & $\begin{array}{l}\text { Фиксация тревоги и огра- } \\
\text { ничительное поведение }\end{array}$ & 0,952 & 92,81 & 92,32 \\
\hline & $\begin{array}{l}8 \text { шKa- } \\
\wedge a \\
\text { (Sc) } \\
\end{array}$ & Аутизация & 0,639 & 90,07 & 93,89 \\
\hline & $\begin{array}{l}9 \text { шка- } \\
\wedge a \\
\text { (Ma) } \\
\end{array}$ & $\begin{array}{l}\text { Отрицание тревоги, гипо- } \\
\text { маниакальные тенденции }\end{array}$ & 0,706 & 90,55 & 93,62 \\
\hline & $\begin{array}{l}0 \text { шка- } \\
\wedge a(S i)\end{array}$ & Социальные контакты & 0,365 & 87,81 & 95,19 \\
\hline
\end{tabular}


Было выявлено несколько показателей, различия по которым оказались статистически достоверны. Это показатели по методикам «Проба Мюнстерберга» (Vвн, Ивн), «Оперативная память», «Моторная проба Шварцландера», 16-факторный личностный опросник Кеттелла» (ф. N). В соответствии со средним рангом группу успешных специалистов отличают более высокие свойства внимания (объем и избирательность), оперативная память; такие специалисты стараются ставить перед собой такие цели, которые реально могут достичь и которые соответствуют их способностям и возможностям, склонны к планированию, контролю эмоций, объективной оценке себя и других. Для группы «средних» характерны более низкие показатели свойств внимания и оперативной памяти, недостаточная уверенность в своих силах и достижении цели, нечеткость в поведении, неопытность в социальных отношениях. А также, в связи с тем, что получено небольшое количество значимых различий по показателям, можно сделать вывод, что в рамках изучения специалистов ГИМС МЧС России трудно подобрать репрезентативную выборку, отражающую свойства эмпирической выборки.

В связи с тем, что успешные специалисты все-таки действительно обладают определенными личностными и психофизиологическими характеристиками, которые влияют на эффективность выполнения ими своей профессиональной деятельности, была проведена оценка достоверности различий между полярными группами успешных и неуспешных по свойствам, признанным экспертами необходимыми для осуществления профессиональной деятельности. Сравнение на выявление значимых различий проводилось с помощью непараметрического математического критерия «U-критерий Манна - Уитни». В результате были установлены достоверные различия по переменным, указанным в таблице 3.

\section{Обсуждение результатов}

Любой метод психодиагностики имеет область применения, ограничения в своих возможностях и не пригоден для тотального использования. В связи с этим для удобства анализа результатов мы выделяем комплекс методик, распределенный по трем основным блокам:

1) интеллектуально-мнестический блок;

2) эмоционально-личностный блок;

3) мотивационно-волевой блок.

Таким образом, анализ полученных результатов позволил выделить ПВК инспектора ГИМС МЧС России (по результатам значимых различий между полярными группами успешных и неуспешных) и разнести их по трем блокам (таблица 4). Уровень выраженности каждого ПВК определялся по среднему значению показателя в группе успешных специалистов. 
Таблица 3. Аостоверность различий межАу полярными группами успешных и неуспешных специалистов

Table 3. Significance of differences between the polar groups of successful and unsuccessful professionals

\begin{tabular}{|c|c|c|c|c|c|}
\hline \multirow{2}{*}{ 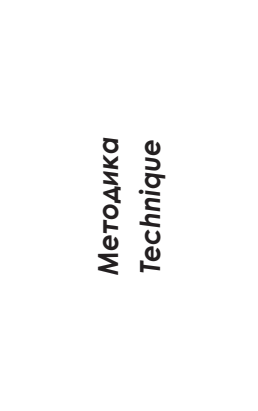 } & \multirow{2}{*}{ 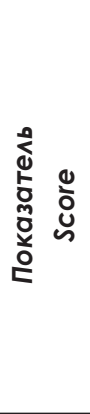 } & \multirow{2}{*}{ 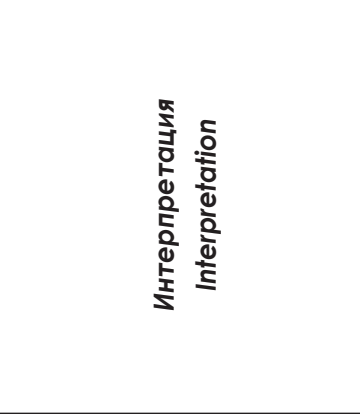 } & \multirow{2}{*}{ 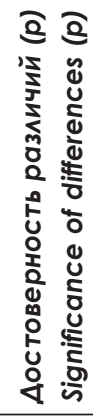 } & \multicolumn{2}{|c|}{ 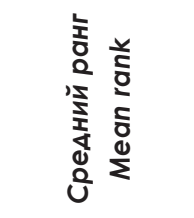 } \\
\hline & & & & 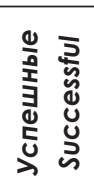 & 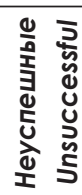 \\
\hline $\begin{array}{l}\text { «Тест возраста- } \\
\text { ющей трудности } \\
\text { А. Равена» } 30 \\
\text { заданий (1, } 2 \\
\text { варианты) }\end{array}$ & Иб & $\begin{array}{l}\text { Уровень развития базо- } \\
\text { вого интемлекта }\end{array}$ & 0,014 & 73,18 & 56,68 \\
\hline $\begin{array}{l}\text { «Инте^лектуальная } \\
\text { ^аби^ьность» }\end{array}$ & И^ & $\begin{array}{l}\text { Уровень интеллектуаль- } \\
\text { ной ^абильности, харак- } \\
\text { теризующей ^абильность } \\
\text { мышления, скорость } \\
\text { перек^ючения мысли- } \\
\text { тельных процессов }\end{array}$ & 0,002 & 56,84 & 77,93 \\
\hline $\begin{array}{l}\text { «Ко^ьца } \\
\text { АанАО^ьта» }\end{array}$ & Квн & Концентрация внимания & 0,042 & 71,34 & 57,79 \\
\hline \multirow{2}{*}{$\begin{array}{l}\text { «исловой } \\
\text { кваАрат» }\end{array}$} & $\mathrm{V}_{\mathrm{BH}}$ & Объем внимания & 0,000 & 76,17 & 52,80 \\
\hline & Рвн & $\begin{array}{l}\text { Распределение } \\
\text { внимания }\end{array}$ & 0,000 & 76,72 & 52,08 \\
\hline \multirow{2}{*}{$\begin{array}{l}\text { «Проба } \\
\text { Мюнстерберга» }\end{array}$} & $\mathrm{V}_{\mathrm{BH}}$ & Объем внимания & 0,017 & 72,92 & 57,02 \\
\hline & Ивн & $\begin{array}{l}\text { Избирательность } \\
\text { внимания }\end{array}$ & 0,000 & 76,68 & 52,13 \\
\hline
\end{tabular}




\begin{tabular}{|c|c|c|c|c|c|}
\hline \multirow{2}{*}{ 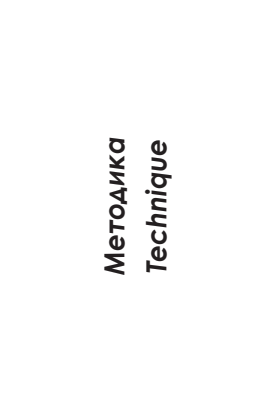 } & \multirow{2}{*}{ 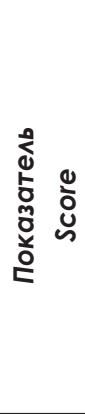 } & \multirow{2}{*}{ 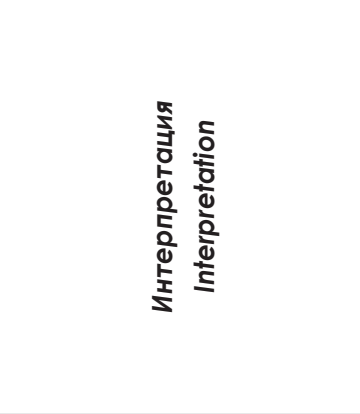 } & \multirow{2}{*}{ 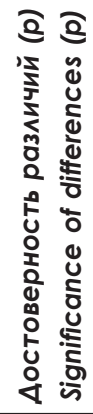 } & \multicolumn{2}{|c|}{ 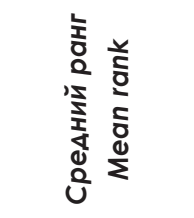 } \\
\hline & & & & 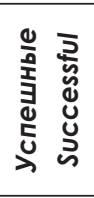 & 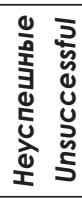 \\
\hline \multirow{3}{*}{$\begin{array}{l}\text { «Запоминание } 10 \\
\text { с^ов» }\end{array}$} & КП। & $\begin{array}{l}\text { Кратковременная память } \\
\text { (1 повторение) }\end{array}$ & 0,009 & 73,39 & 56,40 \\
\hline & КПЗ & $\begin{array}{l}\text { Кратковременная память } \\
\text { (3 повторение) }\end{array}$ & 0,001 & 74,92 & 54,42 \\
\hline & $\Delta \Pi$ & Аолговременная память & 0,003 & 74,26 & 55,27 \\
\hline $\begin{array}{l}\text { «Оценка уровня } \\
\text { субъективного } \\
\text { контроля» }\end{array}$ & YCK & $\begin{array}{l}\text { Уровень субъективного } \\
\text { контроля }\end{array}$ & 0,003 & 74,62 & 54,81 \\
\hline $\begin{array}{l}\text { «16-фрактор- } \\
\text { ный ^ичност- } \\
\text { ный опросник } \\
\text { Кеттем^а» (фрор- } \\
\text { ма А) }\end{array}$ & dp. B & $\begin{array}{l}\text { Высокий интелмект / } \\
\text { низкий интемект (аб- } \\
\text { страктное мышление, } \\
\text { высокая способность } \\
\text { к обучаемости) }\end{array}$ & 0,019 & 72,79 & 57,18 \\
\hline \multirow{2}{*}{$\begin{array}{l}\text { Методика много- } \\
\text { стороннего } \\
\text { исследова- } \\
\text { ния ^ичности } \\
\text { (по Ф.Б. Березину) }\end{array}$} & $\begin{array}{l}5 \\
\text { шкa- } \\
\wedge \mathrm{a} \\
\text { (Mf) }\end{array}$ & $\begin{array}{l}\text { Выраженность муж- } \\
\text { ских и женских черт } \\
\text { характера }\end{array}$ & 0,045 & 62,78 & 50,24 \\
\hline & $\begin{array}{l}0 \\
\text { шKa- } \\
\wedge a \\
\text { (Si) }\end{array}$ & Социальные контакты & 0,031 & 51,83 & 65,30 \\
\hline
\end{tabular}


Таблица 4. Профрессионально важные качества инспектора ГИМС МЧС России

Table 4. Professionally important qualities of inspectors in the SSVI of EMERCOM of Russia

\begin{tabular}{|c|c|}
\hline $\begin{array}{l}\text { Б^ок методик } \\
\text { Techniques }\end{array}$ & $\begin{array}{l}\text { Професссионально важные качества } \\
\text { Professionally important qualities }\end{array}$ \\
\hline $\begin{array}{l}\text { Интемлектуально- } \\
\text { мнестический блок }\end{array}$ & $\begin{array}{l}\text { 1. Уровень развития базового интелмекта не ниже } \\
\text { среднего. } \\
\text { 2. Уровень развития абстрактного и оперативного } \\
\text { мышления не ниже среднего; высокая способность } \\
\text { к быстрому овладению и усвоению новых навыков } \\
\text { и умений. } \\
\text { 3. Интелмектуальная ^абильность не ниже среднего } \\
\text { уровня. } \\
\text { 4. Объем внимания не ниже среднего уровня. } \\
\text { 5. Концентрация внимания не ниже среднего уровня. } \\
\text { 6. Избирательность внимания не ниже среднего } \\
\text { уровня. } \\
\text { 7. Распределение внимания не ниже среднего } \\
\text { уровня. } \\
\text { 8. Уровень развития кратковременной памяти не } \\
\text { ниже среднего уровня. } \\
\text { 9. Уровень развития Аолговременной памяти не ниже } \\
\text { среднего уровня. }\end{array}$ \\
\hline $\begin{array}{l}\text { Эмоциона^ьно- } \\
\text { ^ичностный б^ок }\end{array}$ & $\begin{array}{l}\text { 1. Гармонично развитая личность (психическая } \\
\text { норма). } \\
\text { 2. Социальная экстраверсия (способность к актив- } \\
\text { ным действиям, установлению большого количества } \\
\text { социальных связей, социальная ответственность). } \\
\text { 3. Развитые коммуникативные качества (коммуника- } \\
\text { тивные навыки, общительность). } \\
\text { 4. Сфоормированные морально-этические нормы. } \\
\text { 5. Высокий волевой контроль эмоциональной и пове- } \\
\text { денческой сорер. } \\
\text { 6. Кондрормность. } \\
\text { 7. Способность к эмпатии. }\end{array}$ \\
\hline $\begin{array}{l}\text { Мотивационно-волевой } \\
\text { б^ок }\end{array}$ & $\begin{array}{l}\text { 1. Интернальный / смешанный ^окус контроля. } \\
\text { 2. Мотивация Аостижения успеха. }\end{array}$ \\
\hline
\end{tabular}




\section{Заключение}

Проведенное исследование позволило сделать следующие выводы:

1. Данное исследование связано с изучением психологических особенностей профессиональной деятельности инспекторов ГИМС МЧС России в целях повышения качества проведения профессионального психологического отбора, поэтому возникла необходимость более подробно рассмотреть внутренние характеристики их профессиональной деятельности, а именно психологическую составляющую.

2. В основе профессионально-психологического отбора лежат концепции социально-психологической адаптации и способностей личности, системогенеза, теории функциональных состояний и теории адаптации, личностнодеятельностного подхода.

3. Анализ профессиональной деятельности инспекторов ГИМС МЧС России позволил выявить неблагоприятные стресс-факторы: работу в сложных гидрометеорологических условиях, зачастую на территориях с ухудшением санитарно-эпидемиологической обстановки, в местах массового скопления людей; напряжение и угрозу собственной жизни и здоровью; значительные физические, нервно-психологические нагрузки при ликвидации аварий, катастроф и чрезвычайных ситуаций. Все это предъявляет повышенные требования не только к состоянию здоровья, уровню профессиональной подготовки, но и к ПВК данных специалистов.

4. Любая деятельность реализуется на базе системы ПВК, представляющей собой набор своеобразных симптомокомплексов субъективных свойств, специфических для той или иной профессиональной деятельности.

5. Профессионально важные качества являются одним из важнейших компонентов личности, необходимых для эффективного и успешного выполнения профессиональной деятельности.

6. Проведена сравнительная процедура успешных и неуспешных специалистов по качествам, признанным экспертами необходимыми для выполнения профессиональных задач, в результате чего выявлены значимые различия. Таким образом, изучаемые характеристики являются достаточными для прогнозирования успешности профессиональной деятельности, следовательно, и профессионально важными.

7. Результаты психодиагностического обследования позволили выделить ПВК личности инспектора ГИМС МЧС России, обеспечивающие высокий уровень эффективности выполняемой деятельности, а также являющиеся средством для прогнозирования успешности профессиональной деятельности при профессиональном отборе: особенности интеллектуально-мнестической сферы (развитие базового интеллекта, развитие абстрактного и оперативного мышления, развитые свойства внимания и памяти, устойчивость 
интеллектуальной деятельности в условиях дефицита времени, высокая способность к быстрому овладению и усвоению новых навыков и умений), эмоционально-личностной сферы (коммуникативные качества, волевой контроль эмоций и поведения, эмпатия, социальная активность и адаптивность), мотивационно-волевой сферы (мотивация достижения успеха, готовность нести ответственность за принимаемые решения).

8. Выделенные ПВК инспектора ГИМС МЧС России позволят внести вклад в оптимизацию и систематизацию мероприятий по профессиональному психологическому отбору в системе МЧС России, т. к. делают возможной оценку степени соответствия психологических качеств и свойств кандидата требованиям специальности. Это, в свою очередь, является необходимым условием для избегания психических травм, психосоматических и других заболеваний, связанных с профессиональной деятельностью.

\section{Литература}

1. Бодров В. А. Современные исследования фундаментальных и прикладных проблем психологии профессиональной деятельности. Ч. 1 // Психологический журнал. - 2008. - № 5. - С. 83-90.

2. Дебольский М. Г. Научно-методические основы подготовки практических психологов в Академии управлении МВД России // Академия управления: история, современность, перспективы. Материалы Юбилейной сессии Ученого совета, посвященной 25-летию Академии управления МВД России. - М. : Академия управления МВД России, 2000. - С. 92-102.

3. РодыгинаЮ. К. Особенности личностной структуры лиц экстремальных профессий // Ученые записки университета Лесгафта. - 2009. - № 8. С. 106-109.

4. Леонтьев А. Н. Деятельность. Сознание. Личность. - М. : Смысл ; Академия, 2004. - 352 с.

5. Климов Е. А. Введение в психологию труда. - М. : ИЦ «Академия», 2004. $336 \mathrm{c.}$

6. Шадриков В. Д. Проблемы профессиональных способностей // Психологический журнал. - 1982. - № 5. - С. 13-26.

7. Марищук В. Л. Психологические основы формирования профессионально значимых качеств : дисс. ... д. психол. наук. - Л., 1982. - 351 с.

8. Ильин Е. П. Дифференциальная психология профессиональной деятельности. - СПб. : Питер, 2011. - 432 с.

9. Котелова Ю. В. Очерки по психологии труда. - М. : Изд-во МГУ, 1986. $120 \mathrm{c}$.

10. Психология труда : учеб. для студентов вузов / под ред. проф. А. В. Карпова. - М. : ВЛАДОС-ПРЕСС, 2005. - 350 с. 
11. Мягких Н. И. Профессиональный психологический отбор в органах внутренних дел Российской Федерации (Концепция, принципы, критерии, технологии) : дисс. ... канд. психол. наук. - М., 2004. - 174 с.

12. Основы психодиагностики. Учебное пособие для студентов педвузов / под общ. ред. А. Г. Шмелева. - М. , Ростов н/Д : Феникс, 1996. - 544 с.

13. Иванова Е. М. Психотехнология изучения человека в трудовой деятельности. - М. : Изд-во МГУ, 1992. - 93 с.

14. Дикая Л. Г. Актуальные проблемы и перспективы исследований в психологии труда в условиях глобализации // Психологический журнал. 2007. - Т. 28, № 3. - С. 29-44.

15. Небылицын В.Д. Психофизиологические исследования индивидуальных различий. - М. : Наука, 1976. - 336 с.

16. Super D. E. The psychology of careers. - N.Y. : Harper and Row, 1957. - 258 p.

17. Nuttin J., Lens W. Future time perspective and motivation: Theory and research method. - Leuven Hillsdale, NJ : Leuven University Press Erbaum, 1985. - $235 \mathrm{p}$.

18. Тарасова А. А., Казакова И. А. Изучение индивидуально-психологических и психофизиологических особенностей личности в рамках психодиагностических мероприятий в системе МЧС России // II Всероссийский съезд психологов силовых структур Российской Федерации. Сборник материалов. - М. : Изд-во ФКУ ЦЭПП МЧС России, 2016. - С. 165-175.

19. Шойгу Ю. С. Профессиональный психологический отбор курсантов вузов МЧС России - будущих спасателей (Обоснование психодиагностического инструментария) : дисс. ... канд. психол. наук. - СПб., 2003. $168 \mathrm{c}$.

20. Анастази А. Дифференциальная психология. Индивидуальные и групповые различия в поведении. - М. : Апрель-Пресс, 2001. - 752 с.

21. Дружинин В. Н. Психология общих способностей. - СПб. : Питер, 2007. 3-е изд. - 368 с.

22. Маклаков А. Г. Профессиональный психологический отбор персонала. Теория и практика : Учебник для вузов. - СПб. : Питер, 2008. - 480 с.

23. Eysenck $H$. J. The structure of human personality. - London : Methuen, 1960. - 214 p.

24. Алексеева И., Батаршев А. В., Майорова Е. Диагностика профессионально важных качеств. - СПб. : Питер, 2007. - 192 с.

25. Бодров В. А. Практикум по дифференциальной психодиагностике профессиональной пригодности. - М. : ПЕР СЭ, 2003. - 768 с.

26. Maslow A. H. Motivation and Personality. - N.Y.: Harper and Row, 1954. - 411 p.

27. Гуцыкова С. В. Метод экспертных оценок: теория и практика. - М. : Издво ИП РАН, 2011. - 92 с. 
28. Day D. V., Silverman S. B. Personality and job performance: evidence of incremental validity // Personnel Psychology. - 1989. - Vol. 42. - P. 25-36. DOI: $10.1111 /$ j.1744-6570.1989.tb01549.x

29. Ericsson K. A., Krampe R. T., Tesch-Romer C. The role of deliberate practice in the acquisition of expert performance // Psychological Review. - 1993. Vol. 100. - P. 363-406. - DOI: 10.1037//0033-295X.100.3.363

30. Наследов А. Д. Математические методы психологического исследования. - СПб. : Речь, 2008. - 392 с.

\section{References}

1. Bodrov V. A. Modern studies of fundamental and applied problems in the psychology of professional activity. Part 1. Psikhologicheskii zhurnal, 2008, no. 5, pp. 83-90 (in Russian).

2. Debol'skii M. G. Nauchno-metodicheskie osnovy podgotovki prakticheskikh psikhologov v Akademii upravlenii MVD Rossii [Scientific methodical training of practicing psychologists in the Academy of Management of the Ministry of Internal Affairs of Russia]. Materialy Yubileinoi sessii Uchenogo soveta, posvyashchennoi 25-letiyu Akademii upravleniya MVD Rossii "Akademiya upravleniya: istoriya, sovremennost', perspektivy" [Proc. the Anniversary Scientific Council Session dedicated to the 25th anniversary of the Academy of Management of the Ministry of Internal Affairs of Russia "The Academy of Management: The present, history, and prospects"]. Moscow, Academy of Management Publ., 2000, pp. 92-102.

3. Rodygina Yu. K. Personality structure in individuals of extreme professions. Uchenyezapiski universiteta imeni P.F. Lesgafta, 2009, no. 8, pp. 106-109 (in Russian).

4. Leont'ev A. N. Deyatel'nost'. Soznanie. Lichnost' [Activity, consciousness and personality]. Moscow, Smysl Publ., Akademiya Publ., 2004. 352 p.

5. Klimov E. A. Vvedenie v psikhologiyu truda [An introduction to labor psychology]. Moscow, Akademiya Publ., 2004. 336 p.

6. Shadrikov V. D. Problemy professional'nykh sposobnostei [Problems of professional abilities]. Psikhologicheskii Zhurnal, 1982, no. 5, pp. 13-26 (in Russian).

7. Marishchuk V. L. Psikhologicheskie osnovy formirovaniya professional'no znachimykh kachestv [Psychological foundations of professionally important qualities]. Diss. Cand. Sci. (Psych.). Leningrad, 1982. 351 p.

8. Il'in E. P. Differentsial'naya psikhologiya professional'noi deyatel'nosti [Differential psychology of professional activity]. St. Petersburg, Piter Publ., $2011.432 \mathrm{p}$.

9. Kotelova Yu. V. Ocherki po psikhologii truda [A sketch of labor psychology]. Moscow, MSU Publ., 1986. 120 p. 
10. Karpov A. V. (ed.) Psikhologiya truda [Labor psychology]. Moscow, Vlados Press, 2005. 350 p.

11. Myagkikh N. I. Professional'nyi psikhologicheskii otborvorganakh vnutrennikh del Rossiiskoi Federatsii (Kontseptsiya, printsipy, kriterii, tekhnologii) [Professional psychological selection in the internal affairs bodies of the Russian Federation: A concept, principles, criteria, and technology]. Diss. Cand. Sci. (Psych.). Moscow, 2004. 174 p.

12. Shmelev A. G. (ed.) Osnovy psikhodiagnostiki [Fundamentals of psychodiagnostics]. Rostov-on-Don, Feniks Publ., 1996. 544 p.

13. Ivanova E. M. Psikhotekhnologiya izucheniya cheloveka v trudovoi deyatel'nosti [Psychotechnology of studying a man in labour activity]. Moscow, MSU Publ., 1992. 93 p.

14. Dikaya L. G. Actual problems and research prospects in labour psychology in the conditions of globalization. Psikhologicheskii Zhurnal, 2007, V. 28, no. 3, pp. 29-44 (in Russian).

15. Nebylitsyn V. D. Psikhofiziologicheskie issledovaniya individual'nykh razlichii [Psychophysiological studies of individual differences]. Moscow, Nauka Publ., 1976. 336 p.

16. Super D. E. The psychology of careers. N.Y., Harper and Row, 1957. 258 p.

17. Nuttin J., Lens W. Future time perspective and motivation: Theory and research method. Leuven Hillsdale, NJ, Leuven University Press Erbaum, 1985. 235 p.

18. Tarasova A. A., Kazakova I. A. Izuchenie individual'no-psikhologicheskikh i psikhofiziologicheskikh osobennostei lichnosti v ramkakh psikhodiagnosticheskikh meropriyatii v sisteme MChS Rossii [Individual psychological and psychophysiological personality characteristics in psychodiagnostics in the system of EMERCOM of Russia]. Sbornik materialov II Vserossiiskii s"ezd psikhologov silovykh struktur Rossiiskoi Federatsii [Proc. the 2nd All-Russian Congress of Psychologists of Power Structures of the Russian Federation]. Moscow, Center for Emergency Psychological Aid of EMERCOM of Russia Publ., 2016, pp. 165-175.

19. Shoigu Ju. S. Professional'nyi psikhologicheskii otbor kursantov vuzov MChS Rossii - budushchikh spasatelei (Obosnovanie psikhodiagnosticheskogo instrumentariya) [Professional psychological selection of cadets (the future rescuers) in educational institutions of EMERCOM of Russia: Grounds for psychodiagnostic tools]. Diss. Cand. Sci. (Psych.). St. Petersburg, 2003. 168 p.

20. Anastasi A. Differential psychology. Individual and group differences in behavior (Russ. ed.: Anastazi A. Differentsial'naya psikhologiya. Individual'nye i gruppovye razlichiya v povedenii. Moscow, Aprel' Press, 2001. 752 p.).

21. Druzhinin V. N. Psikhologiya obshchikh sposobnostei [Psychology of general abilities]. St. Petersburg, Piter Publ., 2007. 368 p. 
22. Maklakov A. G. Professional'nyi psikhologicheskii otbor personala. Teoriya i praktika [Professional psychological selection of personnel: Theory and practice]. St. Petersburg, Piter Publ., 2008. 480 p.

23. Eysenck H. J. The structure of human personality. London, Methuen, 1960. $214 \mathrm{p}$.

24. Alekseeva I., Batarshev A. V., Maiorova E. Diagnostika professional'no vazhnykh kachestv [Diagnostics of professionally important qualities]. St. Petersburg, Piter Publ., 2007. 192 p.

25. Bodrov V. A. Praktikum po differentsial'noi psikhodiagnostike professional'noi prigodnosti [Differential psychodiagnostics of occupational fitness]. Moscow, PER SE Publ., 2003. 768 p.

26. Maslow A. H. Motivation and personality. N.Y., Harper and Row Publ., 1954. $411 \mathrm{p}$.

27. Gutsykova S. V. Metod ekspertnykh otsenok: teoriya i praktika [Expert evaluation method:Theory and practice]. Moscow, Institute of Psychology, Russian Academy of Sciences Publ., 2011. 92 p.

28. Day D. V., Silverman S. B. Personality and job performance: Evidence of incremental validity. Personnel Psychology, 1989, V. 42, pp. 25-36. DOI: 10.1111/j.1744-6570.1989.tb01549.x

29. Ericsson K. A., Krampe R. T., Tesch-Romer C. The role of deliberate practice in the acquisition of expert performance. Psychological Review, 1993, V. 100, pp. 363-406. DOI: 10.1037//0033-295X.100.3.363

30. Nasledov A. D. Matematicheskie metody psikhologicheskogo issledovaniya [Mathematical methods of psychological research]. St. Petersburg, Rech' Publ., 2008. 392 p. 